\title{
Editorial
}

\section{Tax Expenditures: Friend or Foe?}

\author{
Barry Bracewell-Milnes, Banstead
}

Most Intertax readers will have heard of 'tax expenditures'. This concept is the brainchild of the late Professor Stanley Surrey and colleagues in the United States and has been exported to much of the English-speaking world and to other countries such as Germany and the Netherlands. The idea is that tax allowances, reliefs, exemptions and other concessions are a form of government expenditure comparable with government expenditure in the common sense of that term. There are two variants of this idea. The objective definition of 'tax expenditures' is any form of allowance, relief, exemption or other concession, including personal allowances against taxes on income and capital. The subjective definition excludes personal allowances against income and capital, since tax expenditures are measured against a 'normal' tax structure which includes schedules of tax rates graduated ad personam.

The concept of tax expenditures is valid in certain contexts. It is right that tax reliefs should be costed; and tax reliefs and government spending may represent alternative means to the same end, to be judged on their relative advantages and disadvantages. But the belief that 'tax expenditures' are similar in substance to government spending rests on a number of assumptions:

- the volume and pattern of the taxpayer's activity are unaffected by the tax relief;

- the effect of tax reliefs on the yield of the rest of the tax system can legitimately be ignored;

- the administrative and compliance costs of tax reliefs are the same as for government spending or no lower;

- the taxpayer is homo economicus, interested only in cash flow, and not interested in differences of quality or character between different flows;

- there is an identifiable tax norm, a 'normal' system, against which the deviations constituted by tax reliefs can be measured.

None of these assumptions is valid.

Tax reliefs can sharpen incentives as much as reductions in rates of tax and can thus affect behaviour. They can thus reduce the 'excess burden' represented by the distortion through taxation of the non-tax pattern of activity.

Similarly, tax reliefs, like reductions in tax rates, increase the yield of the rest of the tax system, since the additional funds at the disposal of the taxpayer increase the volume of activities subject to tax.

Government spending must be financed by taxation, and both taxing and spending impose costs of administration and compliance on the tax authorities and economic agents. Tax reliefs avoid most or all of these costs, since the money concerned remains outside this circuit of taxing and spending. It is particularly helpful to avoid the process of 'churning' whereby money raised in taxation is returned to the same taxpayer in cash or in kind, after deduction of a substantial percentage for the cost of the round trip. An additional dimension of 'churning' is the taxation of government welfare handouts, since the recipient is taxed twice to pay for what he receives.

The taxpayer is not homo economicus interested only in his net cash flow, but homo politicus, approving of some payments and disapproving of others, paying some bills willingly and others reluctantly. It is an observable fact that some taxes are resented more than others, that many people accept a mistake in their favour by the tax authorities but not by an honest trader, that many people who are keen to minimise their tax bills decline to claim government handouts to which they are legally entitled. The present United Kingdom Government has for many years had a policy of reducing the shares of gross domestic product taken in taxation and government spending: a move from government spending of tax reliefs to finance a particular activity assists the realisation of this policy, whereas the taxation of government handouts is especially counter-productive. More generally:

- tax relief improves the neutrality of private competition with government services provided free at the point of consumption. The taxpayer no longer has to pay a second time out of taxed income; 
- tax relief is potentially a good bargain for the government, since the taxpayer does not obtain relief unless he makes a larger cash contribution himself;

- tax relief is a reform in which all participants are volunteers, since nobody is obliged to apply for relief;

- tax relief is a gradualist reform, which builds on established successes.

An example from the United Kingdom shows why the subjective concept of tax expenditures is unsatisfactory. Before the reform of income tax in the early 1970s, the rates of tax were those charged on investment income, and earned income over certain ranges attracted reliefs. After the change of system, the rates of tax were those charged on earned income, and investment income over certain ranges attracted a surcharge. The same distinction was made in the same direction before and after the change; but according to the subjective concept of tax expenditures, there was a tax expenditure before the change and not after. It is therefore regrettable that the Inland Revenue in Inland Revenue Statistics 1993 has abandoned the objective for the subjective approach, calling the table concerned 'Tax expenditures and structural reliefs' instead of 'Costs of direct tax allowances and reliefs in force'.

Tax reliefs have powerful enemies in the United Kingdom. The Treasury dislikes them because they cost tax revenue. The spending Departments dislike them because they threaten their budgets. Inside and outside the tax and economic professions, there are those who for ideological reasons wish to keep the tax system clean and free of encrustations and oppose tax reliefs on the ground that they distort the economy (as though government spending did not distort it still more). 'Tax expenditure' is a phrase that suits the purposes of these people. It is a piece of aggressive nomenclature that seeks to pre-empt the argument by precluding discussion on neutral terms; it is one of those phrases (like 'social justice' or 'national insurance') in which the adjective so qualifies the noun as almost to obliterate its original meaning. The value of the idea is its insistence that tax reliefs should be costed; beyond that, by representing tax reliefs as a form of government spending, which they are not, the concept of tax expenditures disorients the discussion of public policy and is the enemy rather than the ally of rational decision-making. 